\title{
The Gasotransmitter Hydrogen Sulfide and the Neuropeptide Oxytocin as Potential Mediators of Beneficial Cardiovascular Effects through Meditation after Traumatic Events
}

\author{
Oscar McCook $^{1, *(\mathbb{D})}$, Nicole Denoix ${ }^{1,2}$ and Tamara Merz ${ }^{1}$ (D) \\ 1 Institute for Anesthesiological Pathophysiology and Process Engineering, Ulm University Medical Center, \\ 89081 Ulm, Germany; nicole.denoix@uni-ulm.de (N.D.); tamara.merz@uni-ulm.de (T.M.) \\ 2 Clinic for Psychosomatic Medicine and Psychotherapy, Ulm University Medical Center, 89081 Ulm, Germany \\ * Correspondence: oscar.mccook@uni-ulm.de; Tel.: +49-731-500-60185; Fax: +49-731-500-60162
}

Citation: McCook, O.; Denoix, N.; Merz, T. The Gasotransmitter Hydrogen Sulfide and the Neuropeptide Oxytocin as Potential Mediators of Beneficial Cardiovascular Effects through Meditation after Traumatic Events. Trauma Care 2021, 1, 183-194. https:/ / doi.org/10.3390/traumacare1030016

Received: 29 August 2021

Accepted: 3 November 2021

Published: 5 November 2021

Publisher's Note: MDPI stays neutral with regard to jurisdictional claims in published maps and institutional affiliations.

Copyright: (c) 2021 by the authors. Licensee MDPI, Basel, Switzerland. This article is an open access article distributed under the terms and conditions of the Creative Commons Attribution (CC BY) license (https:/ / creativecommons.org/licenses/by/ $4.0 /)$.

\begin{abstract}
Trauma and its related psychological and somatic consequences are associated with higher cardiovascular morbidity. The regulation of both the gasotransmitter hydrogen sulfide $\left(\mathrm{H}_{2} \mathrm{~S}\right)$ and the neuropeptide oxytocin (OT) have been reported to be affected during physical and psychological trauma. Both mediators are likely molecular correlates of trauma-induced cardiovascular complications, because they share parallel roles and signaling pathways in the cardiovascular system, both locally as well as on the level of central regulation and the vagus nerve. Meditation can alter the structure of specific brain regions and can have beneficial effects on cardiovascular health. This perspective article summarizes the evidence pointing toward the significance of $\mathrm{H}_{2} \mathrm{~S}$ and OT signaling in meditation-mediated cardio-protection.
\end{abstract}

Keywords: vagus nerve; post-traumatic stress disorder; hypothalamic-pituitary-adrenal-axis

\section{Introduction}

Trauma is associated with a higher risk of cardiovascular disease and dysfunction as well as increased morbidity and mortality [1-4]. Recently, the gasotransmitter hydrogen sulfide $\left(\mathrm{H}_{2} \mathrm{~S}\right)$ and the neuroendocrine oxytocin (OT) systems have been shown to interact and play parallel roles in the heart and brain in response to both physical and psychological trauma [1,5-10]. Trauma can be either a result of physical injury or have a psychological origin, in the latter case caused by a life-threatening deep emotional pain [11]. Physical trauma is associated with a serious injury to the body caused by an impact, wound, or even surgery. Furthermore, both physical and psychological trauma can have long-term effects on mental health, since they can induce post-traumatic stress disorder (PTSD), which causes the patient to relive traumatic events and is commonly associated with psychological co-morbidities such as depression, anxiety, and substance abuse. A recent example of a stress-induced cardiomyopathy, which is only reportedly present in adults (mostly postmenopausal women), soon after experiencing a sudden unexpected emotional or physical stressor is Takotsubo cardiomyopathy, also known as broken heart syndrome [12]. Takotsubo cardiomyopathy is characterized by left ventricular dysfunction that mimics a myocardial infarct but in the absence of coronary artery disease and is in many cases reversible [12]. It has recently been established that both physical and psychological trauma share somatic correlates [1,2,13]. Meditation has been shown to reduce blood pressure, heart rate, and physiologic markers of stress [14]. Furthermore, in 2017, the American Heart Association recommended meditation as an adjunct to guideline-directed interventions for cardiovascular risk reduction $[15,16]$, although the exact mechanisms by which meditation confers its cardiovascular benefits are not known. This perspective will explore the potential role of the $\mathrm{H}_{2} \mathrm{~S}$ and OT systems via the vagus nerve, the link between the brain and the heart, in mediating cardiac protection through meditation. 


\section{Early Life Stress}

The significance of early life stress (ELS) in the developmental origins of cardiometabolic disease such as arthrosclerosis, MI, stroke, arterial hypertension, chronic heart failure, ischemic, coronary heart disease, and diabetes type 2 is now well established [17-20]. ELS is multifactorial and can be broken down into childhood maltreatment (physical, sexual, and psychological abuse, maternal separation and/or neglect), as well as stressful life events that can be traced back to the womb as the pioneering work of Higgins et al. indicated [21]. Recent studies have suggested that the cardiovascular programming resulting in cardiovascular disease (CVD) share common mechanisms. Although they are not fully understood, the experimental evidence implicates oxidative stress, nitric oxide (NO), renin angiotensin system, nutrient-sensing signals, and gut microbiota dysbiosis [22-25]. $\mathrm{OT}$ and $\mathrm{H}_{2} \mathrm{~S}$ systems have been shown to be cardioprotective and display antioxidant and anti-inflammatory properties in models of psychological and physical trauma [2,26-29]. As will be briefly shown below, both the $\mathrm{H}_{2} \mathrm{~S}$ and OT systems have been shown to interact in these very mechanisms instrumental in cardiac programming, a more extensive look at the role of the $\mathrm{H}_{2} \mathrm{~S}$ and OT systems in ELS-mediated CVD has been recently reviewed by McCook et al., 2021 [1].

\section{3. $\mathrm{H}_{2} \mathrm{~S}$ System}

$\mathrm{H}_{2} \mathrm{~S}$ is one of three known gasotransmitters, alongside $\mathrm{NO}$ and carbon monoxide, and it is produced endogenously by cystathionine $\gamma$-lyase (CSE), cystathionine $\beta$-synthase (CBS), and 3-mercaptopyruvate sulphurtransferase (3MST) [30]. $\mathrm{H}_{2} \mathrm{~S}$ or its endogenous enzymes have been reported to be produced in the cardiovascular system specifically in the following cell types: smooth muscle cells, cardiomyocytes, endothelial cells, and immune cells $[2,9,10,31-33]$. Numerous reviews on $\mathrm{H}_{2} \mathrm{~S}$ and its protective effects in the cardiovascular system are available [22,29-31]. In humans, $\mathrm{H}_{2} \mathrm{~S}$ levels correlate with disease severity in hypertensive patients [34] and are significantly reduced in hypertensive children [35]. Furthermore, heart failure patients suffering from severe end-stage cardiomyopathy and with reduced heart function, were shown to have significantly lower $\mathrm{H}_{2} \mathrm{~S}$ levels in comparison to age-matched controls [29] and reduced $\mathrm{NO}$ levels, thus suggesting that atherosclerosis and hypertension are associated with reduced levels of $\mathrm{H}_{2} \mathrm{~S}$. The $\mathrm{H}_{2} \mathrm{~S}$-dependent vasoactive effects are mediated by downstream signaling cascades that stimulate Akt-dependent endothelial NO synthase (eNOS). Wang et al. [36] propose that CSE mediates cardioprotection by upregulating the OT receptor (OTR) through the reperfusion injury salvage kinase (RISK) pathway [5,36]. The RISK pathway has been suggested to be the downstream molecular pathway, where $\mathrm{H}_{2} \mathrm{~S}$ and OT signaling converge in cardio-protection in atherosclerosis [36]. Atherosclerosis is characterized by elevated levels of low-density lipoproteins, decreased high-density lipoproteins, oxidative stress, reduced NO, endothelial dysfunction, and inflammation [37], leading to the formation of fibro-fatty lesions in the vascular wall and is the main cause of death from CVD [37]. Interestingly, the administration of both $\mathrm{H}_{2} \mathrm{~S}$ and OT have been reported to reduce atherosclerotic plaque formation and inflammation [1]. Furthermore, the $\mathrm{H}_{2} \mathrm{~S}$ and OT systems share the downstream signaling mechanisms which converge on the same nitric oxide synthase (NOS)/NO-dependent pathway, which is salient for the future discussion on meditation $[2,29,38]$.

\section{Oxytocin System}

The neuroendocrine OT system is comprised of the nonapeptide OT and the OTR and is based on a ligand-receptor interaction. The binding of OT to its receptor stimulates pro-survival kinases such as ERK and PI3K/Akt, which can in turn activate eNOS or CSE $\left(\mathrm{H}_{2} \mathrm{~S}\right)$ [36]. The NO-mediated vasodilatory effects of OT are also reported to regulate blood pressure [2,39-43] and body fluid homeostasis through an interaction with $\mathrm{H}_{2} \mathrm{~S}[26,44]$. OTR expression has been detected in cardiomyocytes, vasculature (smooth muscle cells and endothelium), macrophages, peripheral blood mononuclear cells, and cardiac fibroblasts $[2,9,45-51]$. There are a number of recent reviews available on the role 
of OT in the heart $[39,46,52,53]$. Many of the cardiovascular properties reported for OT are similar to those cited for $\mathrm{H}_{2} \mathrm{~S}$, e.g., increase in the glucose uptake in cardiac cells, anti-inflammatory and antioxidant activity [54-56], blood-pressure-lowering capacities via NO-mediated vasodilation [57], negative inotropic and chronotropic effects, natriuretic effects, and effects on endothelial cell growth [58-60].

Recently, a more direct connection between the $\mathrm{H}_{2} \mathrm{~S}$ and OT systems was shown in an acute chronic mouse model of traumatic injury in response to cardiovascular injury. In mice, trauma significantly reduced the cardiac OTR expression, and this downregulation was further aggravated in mice with genetic CSE deletion. Furthermore, the loss of cardiac OTR was restored by exogenous $\mathrm{H}_{2} \mathrm{~S}$ administration through the slow-releasing $\mathrm{H}_{2} \mathrm{~S}$ donor GYY4137 [9]. Additionally, naïve CSE knock out (ko) mice had lower levels of OTR [2], and similarly, naïve mice with a genetic deletion of OTR presented with a reduction in CSE expression [8].

Psychological stress increases blood pressure and heart rate; the chemical blockade of the OTR was shown to worsen the cardiovascular response to stress [61-64]. In rodent models of maternal separation, the neonates respond with increased inflammation, and OT infusion has been shown to be beneficial $[65,66]$. Interestingly, a parallel response of the $\mathrm{H}_{2} \mathrm{~S}$ and OT systems was recently reported in response to ELS. In a mouse model of maternal separation, the authors reported that long term separation stress (LTSS) led to a long-term reduction in the cardiac OTR and CSE expression of adult mice exposed to ELS [8]. It is striking that these experiments in a psychological trauma model reported similar findings regarding cardiac OTR and CSE expression as those reported by Merz et al. [9] in a combined acute on chronic physical trauma model where there was a down regulation of the OTR in cardiac tissue. Furthermore, the genetic deletion of 3MST, another endogenous $\mathrm{H}_{2} \mathrm{~S}$ producing enzyme, led to hypertension and cardiac hypertrophy, which was accompanied with increased anxiety-like behavior in old age [67]. In another experiment, mice with a genetic mutation of 3MST presented with reduced cardiac CSE and OTR expression both in the naive and post-injury state [5], thus suggesting an important, yet not fully resolved, role for 3MST in the context of stress-induced cardiovascular disease. This also provides further support for the mutual and interrelated role of $\mathrm{H}_{2} \mathrm{~S}$ and OT systems in both physical and psychological trauma [5].

\section{Hypothalamic-Pituitary-Adrenal Axis and Brain}

The hypothalamic-pituitary-adrenal axis (HPA) plays key roles in basal homeostasis and responding to both external and internal stimuli in the body's response to stress. These include psychological stressors, and, hence, the HPA is also postulated to be involved in the vulnerability to psychological pathologies [68-74]. It has been shown that neglect and abuse lead to the dysregulation of the HPA [75]. OT release is involved in the regulation of cortisol levels and thus helps maintain the balance in the HPA's response to stress [68,76-79]. Specifically, OT release is linked to anxiolytic and anti-depressive behavior by attenuating stress induced HPA activity $[76,80]$. Chronic postnatal stress was shown to affect stress responses in adulthood by increasing OTR gene expression in the hippocampus as a response to secondary stress [76]. In contrast, very recent findings in mice show that intranasal OT administration suppressed the stress response and reversed "deficient emotional contagion", which was accompanied by increased OTR expression in the prefrontal cortex and the hypothalamus [81]. Nonetheless, stress can lead to a suppression of the endogenous production of OT and to the inhibition of negative feedback in the HPA, ultimately leading to hypercortisolemia $[68,82,83]$. Recent results have similarly demonstrated that stress-induced depression is associated with dysregulated $\mathrm{H}_{2} \mathrm{~S}$ generation in the hippocampus [84], in turn, its supplementation inhibits depressive-like behavior, suggesting a novel potential role for $\mathrm{H}_{2} \mathrm{~S}$ as an antidepressant [85].

In a porcine acute subdural hematoma (ASDH) model, the presence of OT/R in the hypothalamus was confirmed and was also found to co-localize with CSE [2,7]. Interestingly, CSE and OTR displayed reciprocal expression patterns in the cerebellum, suggesting that 
different brain regions may differ in the interaction of the $\mathrm{OT}_{2} \mathrm{~S}$ systems [2]. Furthermore, the authors observed the activation of the $\mathrm{H}_{2} \mathrm{~S}$ and OT systems in the prefrontal cortex, which may assume importance because this is one of the brain regions reported to be dysregulated in PTSD. The presence of these two systems may be indicating potentially relevant biological mechanisms of ASDH-induced PTSD [6,86,87].

\section{Brain and Heart-Vagus Nerve- $\mathrm{H}_{2} \mathrm{~S}$ and Oxytocin}

Recently, it has been proposed that a physiological mechanism for the interaction of the $\mathrm{H}_{2} \mathrm{~S}$ and OT systems between the brain and heart is the vagus nerve [1]. The vagus nerve regulates metabolic homeostasis and connects the brain and heart through afferent vagal nerve fibers $(80 \%)$, which control sensory signals towards the brain, and efferent vagal nerve fibers $(20 \%)$, which conduct signals towards peripheral organs such as the heart, lungs, and gastrointestinal tract. In the brain, fibers of the vagus nerve terminate in the nucleus tractus solitaris, which connects to the amygdala, the hypothalamus, and the orbito-frontal cortex [88]. The vagus nerve plays an important role under stress conditions in protecting the heart from being over stimulated [89]. When looking at the brain and nervous system, there is also evidence for a bi-directional effect of the $\mathrm{H}_{2} \mathrm{~S}$ and OT systems in the interaction of the CV and the central nervous system (CNS) [26].

OT acts on sympathetic and vagal outputs to control heart and blood vessel function through oxytocinergic cells in the PVN, which are directly connected to the vagal nuclear complex [90]. The OTR in the PVN fine-tunes the tonic neural control of baroreflex sensitivity, short-term blood pressure variability, and autonomic control in cardiovascular diseases [90]. The inhibition of OT signaling to the vagus nerve may lead to impaired autonomic control in cardiovascular disease [88,90]. The OT-producing magnocellular neurons of the PVN have been shown to directly excite cardiac vagal neurons, and the OT system, in particular during stress and anxiety, has been implicated in the regulation of cardiovascular homeostasis and parasympathetic cardiac activity [91]. The chronic stimulation of OT-producing neurons in the PVN, activating cardiac vagal neurons, increased the parasympathetic tone and reduced cardiac hypertrophy [91]. In myocardial ischemia/reperfusion (I/R) injury, activation of the vagus nerve and attenuated severe arrhythmias led to a reduction in free radical blood levels and reduced mortality [92]. The stimulation of the vagal dorsal motor nucleus in the brainstem lowered respiratory frequency and induced bradycardic responses [93]. OT also mediated cardio-protection through the cardiovascular, respiratory, and immune responses, thus strengthening an autonomic cholinergic link [94]. The authors could show in endotoxemic rats that OT administration (subcutaneously) reduced tachypnea and was beneficial for cardiovascular respiratory coupling, as assessed by the spectral components of heart rate variability [94], which is the main read out for vagus nerve activity [94].

Reports on the role of $\mathrm{H}_{2} \mathrm{~S}$ in vagal-nerve-mediated cardiovascular function are limited at best; nonetheless, a microinjection of an exogenous $\mathrm{H}_{2} \mathrm{~S}$ donor (NaHS) into the dorsal motor nucleus of the vagus nerve led to decreased respiratory frequency and heart rate [95]. In a model of chronic heart failure, the microinjection of GYY4137 into the PVN led to higher renal sympathetic nerve activity, increased blood pressure and heart rate, and was beneficial for the cardiac sympathetic afferent reflex [96]. The endogenous $\mathrm{H}_{2} \mathrm{~S}$-producing enzyme CBS has been localized in the dorsal motor nucleus of the vagus nerve, suggesting local $\mathrm{H}_{2} \mathrm{~S}$ production $[95,97]$. In a more recent study, it is reported that local $\mathrm{H}_{2} \mathrm{~S}$ production by CBS, in the cerebral neural networks that maintain respiration, was responsible for eupnea: the rhythmic three-phase respiratory pattern [98]. The authors showed that when $\mathrm{H}_{2} \mathrm{~S}$ synthesis was inhibited, eupnea was not maintained but turned to gasping and was reflected in decreased vagus nerve activity [98]. " $\mathrm{H}_{2} \mathrm{~S}$ dependent oxygen sensing" by glomus cells in the carotid body is CSE-mediated, and its inhibition leads to failure of the hypoxic response accompanied by a loss of catecholamine release [99,100]. Taken together, the results reported above demonstrate that both $\mathrm{H}_{2} \mathrm{~S}$ and OT directly influence the vagal nerve through stimulation of the PVN, ultimately affecting the heart and the cardiovascular 
system: blood pressure, heart rate, heart rate variability, and cardiovascular tone. OT, in concert with $\mathrm{H}_{2} \mathrm{~S}$, could have a direct physiological interaction, affecting the respiratory system and respiratory patterns, baroreceptor sensitivity, and reactions to hypoxic events in cardiovascular stress.

\section{Meditation (Breath Control)}

Over the last decade, reliable evidence has been accumulating showing the beneficial role of meditation in both mental health and physical wellbeing $[15,16]$. In a meta-analysis and systemic review Pascoe et al. found that in all forms of meditation analyzed, meditation reduced blood pressure, heart rate, and physiological markers of stress: cortisol, $C$ reactive protein, TNF- $\alpha$, and triglycerides [14]. In 2017, the American Heart Association (AHA) suggested the practice of meditation as an adjunct to guideline-directed interventions for cardiovascular risk reduction $[15,16]$. Furthermore, in a very recent study using a large national data base (the National Health Interview Survey) of the US population, all patients with hypercholesterolemia, systemic hypertension, diabetes mellitus, stroke, and coronary artery disease, as well as those reporting to meditate, were identified and contrasted to the non-meditating patients. Meditation was associated with a significant reduction in the incidence of all the parameters measured [15]. Traditional approaches to help prevent CVD focused on modifying behavioral patterns in adults, although, recently, the AHA has suggested that childhood may be an important period to intervene for reducing the risk of CVD over the life span [18]. It was suggested that interventions reducing early risk factors may be more instrumental in early life than interventions that attempt at remediating CVD later in life [19]. Meditation may be the most appropriate intervention in early life to combat the onset of CVD in later life. The authors of the above-mentioned National Health Interview Survey did not define nor limit meditation to a particular kind of meditation technique. There are a large variety of meditational practices in the world, and a discussion on this topic is beyond the scope of this perspective article, but the topic has been adequately reviewed by Dudeja 2017 as well as Gerritsen and Band 2018 [101,102]. What is maybe more relevant is that meditational practices aim at establishing a "relaxation response" and are practiced by more than $30 \%$ of adults in the USA and that this practice counteracts the effects of stress by reducing volumetric oxygen consumption from rest, although the exact mechanism remains unknown [103]. Kaliman et al. [104] reported that mindfulness meditation with experienced meditators versus control (non-meditators) led to changes in epigenetic regulatory enzymes and inflammatory gene expression. The genes analyzed were the same at basal levels for both groups, but after a day of intense meditation, the experienced meditators presented with lower expression of histone deacetylase genes, changes in global modifications of histones, and reduced expression of pro-inflammatory genes [104], thus implying that meditation is able to effect changes in epigenetic programming with beneficial and anti-inflammatory properties. The salubrious effects associated with meditation are incontrovertible, but there are no clear indications as to the why nor the how. "Mindfulness meditation" describes a conscious state characterized by a mental awareness and attention to the present moment and originates from Buddhist meditational techniques: focusing on the breath (Anapanasati) or awareness of body, sensations, mind, and mental phenomena (Satipatthana), or calm abiding (Samatha), leading subsequently to relaxation $[105,106]$.

Interestingly, the intranasal administration of OT reportedly increased feelings of "spirituality" and positive emotions experienced during meditation [107]. Followed by the fact that salivary OT was significantly increased in participants practicing Arigato-Zen meditation in a small study of 32 participants, this may be pointing to a potential mechanism [108]. These recent findings have led to the hypothesis that OT $\left(\mathrm{H}_{2} \mathrm{~S}\right)$ and the HPA axis are good candidates for the explanation of the salubrious effects of meditation [109] (see Figure 1). 


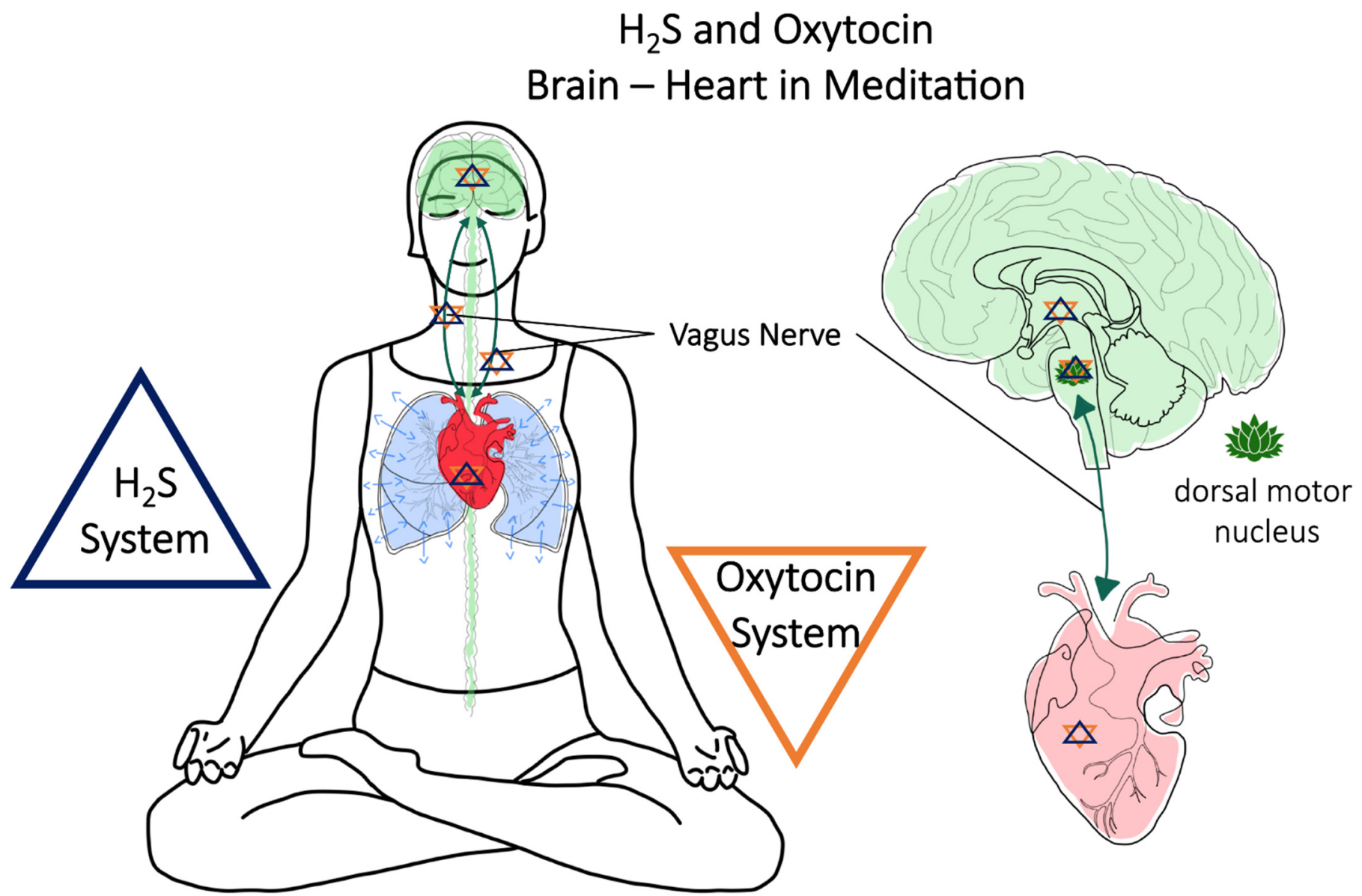

Figure 1. Meditation and conscious breathing are suggested to be able to confer cardio-protection via the vagus nerve and $\mathrm{H}_{2} \mathrm{~S} / \mathrm{OT}$-signaling.

However, the potential mechanism may be hinted at by the study of Kim et al., 2005, where they investigated serum nitrate-nitrite as a surrogate marker for NO and detected higher serum levels of nitrite-nitrate and lower lipid peroxidation in the experienced Zen meditation group vs. the control group [110].

Recalling the previously stated relationship between $\mathrm{H}_{2} \mathrm{~S}$ and OT systems involving the RISK pathway as the downstream molecular pathway, where $\mathrm{H}_{2} \mathrm{~S}$ and OT signaling converge in cardio-protection in atherosclerosis [36] and whose activation leads to PI3K, $\mathrm{Akt}$, and eNOS cascades, we may be starting to glimpse at the mechanisms behind the beneficial effects of meditation.

Very recently, it was reported that guided mindfulness meditation in college students was associated with a significant reduction in negative affect and anxiety concomitantly with an increase in salivary OT in the meditators [111]. In this study there were two $15 \mathrm{~min}$ guided meditation exercises performed at the beginning and end of the sessions: "The purpose of these meditations was to direct one's attention to breathing and physical sensations, trying not to identify with the mental events that arose during this process" [111]. It is noteworthy that the meditating subjects were told to direct their attention to breathing, for it may just be that attentiveness to breath may be another link to the underlying mechanisms that lead to the beneficial effects of meditation. Another piece of the puzzle comes to light when recalling that mindfulness meditation aims at the "relaxation response" because the elicitation of the relaxation response was shown by Durec et al. to correlate with changes of fractional exhaled NO but not with the control group [103]. Intriguingly, Bernardi et al. reported that they "serendipitously" found that the Ave Maria prayer and yoga mantras enhance and synchronize inherent cardiovascular rhythms by slowing respiration to six respirations per minute, the same as the endogenous circulatory rhythms described by 
Mayer [112] in 1876 that is related to both vagal and sympathetic activity [113]. This is echoed by Gerritson and Band, who point out that the threshold for triggering cardiovagal baroreflex sensitivity can be decreased to about six breaths per minute, and lowering the sensitivity leads to decreased heart rate and increased vagal tone [101]. They go on to emphasize that the main mediator of controlled breathing on mental health and cognitive effects is the vagus nerve [105] and further put forth that specific respiratory patterns serve to stimulate the vagus nerve, specifically the slow, deep respiration and extended expiration [101] (see also illustrated in Figure 1).

Interestingly, results from experienced meditators (Masters of Zen and Vipassana) confirmed heart rate variability (HRV) changes during mindfulness meditation with the added caveat that the authors perceived an adaptive function of the autonomic cardiovascular system. This further suggests that it may be part of a dynamic regulatory system integrating the central and autonomic nervous systems and point to its mediation via the vagus nerve in both the regulation of attention and emotion [114].

Finally, the effects of meditation on the brain have also been investigated in neuroimaging studies, and a meta-analysis of brain morphology studies from meditators revealed that eight brain regions were consistently altered (in volume and activity) in meditators (see also Figure 2): frontopolar cortex, sensory cortices and insula, hippocampus, anterior and mid cingulate, orbitofrontal cortex, superior longitudinal fasciculus, and corpus callosum [115]. The prefrontal regions, particularly the orbitofrontal, medial, and lateral prefrontal cortex are able to influence heart rate variability and stimulate endocrine responses via the vagus nerve [101]. However, vagal nerve regulation is bi-directional, and the efferent medullar termini of the vagus nerve also affects the limbic and cortical regions influencing cognitive control [101]. Thus, the central autonomic network can be modified through meditation, and those alterations are reflected in structural and functional changes as evinced by the above neuroimaging studies on meditators. Interestingly, these brain regions affected by meditation are in line with what was reviewed for the OT and $\mathrm{H}_{2} \mathrm{~S}$ systems.

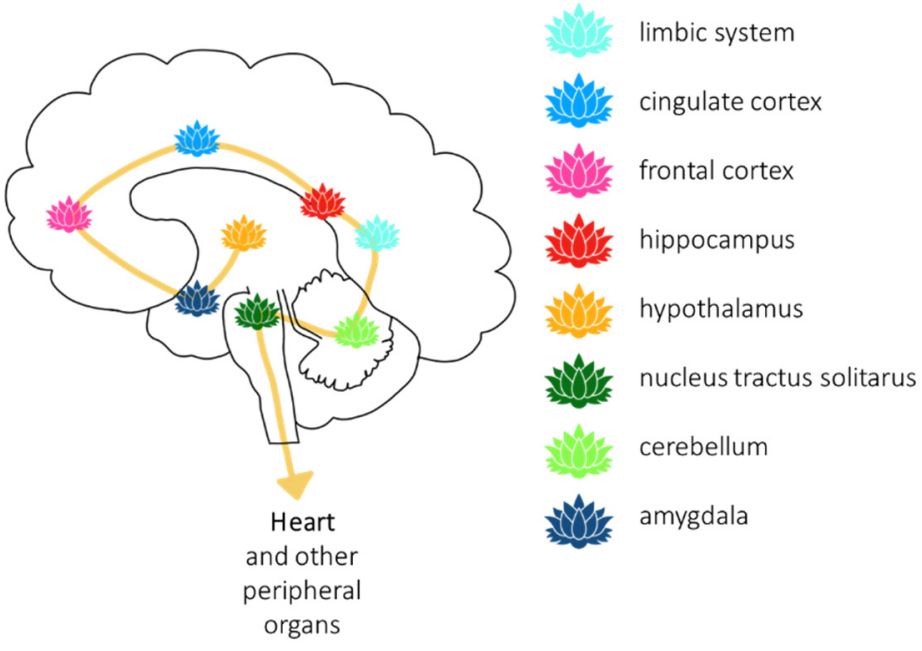

Figure 2. Meditation can change the structure of certain brain regions, which contribute to the regulation of the cardiovascular system.

The reported increase in OT levels as a result of meditation are suggestive of a potential neuroendocrine physiological mechanism for the salubrious effects associated with meditation.

\section{Conclusions}

The parallels and intricacy of the $\mathrm{H}_{2} \mathrm{~S}$ and OT systems, just reviewed, imply their mutual interaction in the communication between the heart and brain via the vagus nerve. However, more importantly, because of the fact that meditation has been shown to be associated with reduced risk of CVD [15], meditation may prove to be a very real, practical, 
inexpensive, alternative, or adjunct practice for all, but particularly in attenuating the ELSmediated developmental origins of CVD. It may just be that meditation would be the ideal therapy for children (who are still undergoing developmental changes) and individuals that have developed resilience or otherwise have a contextual history that may lead to adverse effects of medication.

The last thoughts on the subject of meditation and the OT system go to the following enigmatic yet provocative statements from Erdman:

"This evidence linking the hippocampus and amygdala with oxytocin provides a scientific mechanism liberating downstream ancestral memories catalogued in neuronal networks. Knowing that oxytocin may likewise be boosted during meditation or prayer provides a possible portal to ancestral diaries. Following this logic one step further, the meditating mind struggles to put the knowledge archives into familiar themes, filling in the gaps, and imparting the feelings of a guiding voice or visiting an Akashic Record library. These treasures are unbundled and retrieved under the influence of oxytocin to convey resiliency for survival in life-and death situations." [116].

Author Contributions: Conceptualization, O.M.; writing—original draft preparation, O.M.; writingreview and editing, O.M. and T.M.; visualization, N.D.; supervision, O.M.; funding acquisition, T.M. All authors have read and agreed to the published version of the manuscript.

Funding: TM received funding from the Medical Faculty of Ulm University (Baustein-Programm: LSBN.0192).

Institutional Review Board Statement: Not applicable.

Informed Consent Statement: Not applicable.

Conflicts of Interest: The authors declare no conflict of interest.

\section{References}

1. McCook, O.; Denoix, N.; Radermacher, P.; Waller, C.; Merz, T. $\mathrm{H}_{2} \mathrm{~S}$ and Oxytocin Systems in Early Life Stress and Cardiovascular Disease. J. Clin. Med. 2021, 10, 3484. [CrossRef]

2. Denoix, N.; McCook, O.; Ecker, S.; Wang, R.; Waller, C.; Radermacher, P.; Merz, T. The Interaction of the Endogenous Hydrogen Sulfide and Oxytocin Systems in Fluid Regulation and the Cardiovascular System. Antioxidants 2020, 9, 748. [CrossRef]

3. Wang, C.-Y.; Chen, Y.-C.; Chien, T.-H.; Chang, H.-Y.; Chen, Y.-H.; Chien, C.-Y.; Huang, T.-S. Impact of Comorbidities on the Prognoses of Trauma Patients: Analysis of a Hospital-Based Trauma Registry Database. PLoS ONE 2018, 13, e0194749. [CrossRef]

4. Ferraris, V.A.; Ferraris, S.P.; Saha, S.P. The Relationship Between Mortality and Preexisting Cardiac Disease in 5,971 Trauma Patients. J. Trauma Inj. Infect. Crit. Care 2010, 69, 645-652. [CrossRef]

5. Trautwein, B.; Merz, T.; Denoix, N.; Szabo, C.; Calzia, E.; Radermacher, P.; McCook, O. DMST and the Regulation of Cardiac CSE and OTR Expression in Trauma and Hemorrhage. Antioxidants 2021, 10, 233. [CrossRef]

6. McCook, O.; Scheuerle, A.; Denoix, N.; Kapapa, T.; Radermacher, P.; Merz, T. Localization of the Hydrogen Sulfide and Oxytocin Systems at the Depth of the Sulci in a Porcine Model of Acute Subdural Hematoma. Neural Regen. Res. 2021, 16, $2376-2382$. [CrossRef]

7. Denoix, N.; Merz, T.; Unmuth, S.; Hoffmann, A.; Nespoli, E.; Scheuerle, A.; Huber-Lang, M.; Gündel, H.; Waller, C.; Radermacher, P.; et al. Cerebral Immunohistochemical Characterization of the $\mathrm{H}_{2} \mathrm{~S}$ and the Oxytocin Systems in a Porcine Model of Acute Subdural Hematoma. Front. Neurol. 2020, 11, 649. [CrossRef]

8. Wigger, D.C.; Gröger, N.; Lesse, A.; Krause, S.; Merz, T.; Gündel, H.; Braun, K.; McCook, O.; Radermacher, P.; Bock, J.; et al. Maternal Separation Induces Long-Term Alterations in the Cardiac Oxytocin Receptor and Cystathionine g-Lyase Expression in Mice. Oxid. Med. Cell. Longev. 2020, 2020, 4309605. [CrossRef]

9. Merz, T.; Lukaschewski, B.; Wigger, D.; Rupprecht, A.; Wepler, M.; Gröger, M.; Hartmann, C.; Whiteman, M.; Szabo, C.; Wang, R.; et al. Interaction of the Hydrogen Sulfide System with the Oxytocin System in the Injured Mouse Heart. Intensive Care Med. Exp. 2018, 6, 41. [CrossRef]

10. Merz, T.; Denoix, N.; Wigger, D.; Waller, C.; Wepler, M.; Vettorazzi, S.; Tuckermann, J.; Radermacher, P.; McCook, O. The Role of Glucocorticoid Receptor and Oxytocin Receptor in the Septic Heart in a Clinically Relevant, Resuscitated Porcine Model with Underlying Atherosclerosis. Front. Endocrinol. 2020, 11, 299. [CrossRef]

11. Agorastos, A.; Pervanidou, P.; Chrousos, G.P.; Baker, D.G. Developmental Trajectories of Early Life Stress and Trauma: A Narrative Review on Neurobiological Aspects Beyond Stress System Dysregulation. Front. Psychiatry 2019, 10, 118. [CrossRef] [PubMed] 
12. Akashi, Y.J.; Goldstein, D.S.; Barbaro, G.; Ueyama, T. Takotsubo cardiomyopathy: A new form of acute, reversible heart failure. Circulation 2008, 118, 2754-2762. [CrossRef]

13. Auxéméry, Y. Post-Traumatic Psychiatric Disorders: PTSD Is Not the Only Diagnosis. Presse Méd. 2018, 47, 423-430. [CrossRef]

14. Pascoe, M.C.; Thompson, D.R.; Jenkins, Z.M.; Ski, C.F. Mindfulness Mediates the Physiological Markers of Stress: Systematic Review and Meta-Analysis. J. Psychiatr. Res. 2017, 95, 156-178. [CrossRef]

15. Krittanawong, C.; Kumar, A.; Wang, Z.; Narasimhan, B.; Jneid, H.; Virani, S.S.; Levine, G.N. Meditation and Cardiovascular Health in the US. Am. J. Cardiol. 2020, 131, 23-26. [CrossRef]

16. Levine, G.N.; Lange, R.A.; Bairey-Merz, C.N.; Davidson, R.J.; Jamerson, K.; Mehta, P.K.; Michos, E.D.; Norris, K.; Ray, I.B.; Saban, K.L.; et al. Meditation and Cardiovascular Risk Reduction: A Scientific Statement From the American Heart Association. J. Am. Heart Assoc. 2017, 6, e002218. [CrossRef]

17. Albus, C.; Waller, C.; Fritzsche, K.; Gunold, H.; Haass, M.; Hamann, B.; Kindermann, I.; Köllner, V.; Leithäuser, B.; Marx, N.; et al. Significance of Psychosocial Factors in Cardiology: Update 2018: Position Paper of the German Cardiac Society. Clin. Res. Cardiol. 2019, 108, 1175-1196. [CrossRef]

18. Basu, A.; McLaughlin, K.A.; Misra, S.; Koenen, K.C. Childhood Maltreatment and Health Impact: The Examples of Cardiovascular Disease and Type 2 Diabetes Mellitus in Adults. Clin. Psychol. Sci. Pract. 2017, 24, 125-139. [CrossRef]

19. Suglia, S.F.; Koenen, K.C.; Boynton-Jarrett, R.; Chan, P.S.; Clark, C.J.; Danese, A.; Faith, M.S.; Goldstein, B.I.; Hayman, L.L.; Isasi, C.R.; et al. Childhood and Adolescent Adversity and Cardiometabolic Outcomes: A Scientific Statement from the American Heart Association. Circulation 2018, 137, e15-e28. [CrossRef]

20. Chandan, J.S.; Okoth, K.; Gokhale, K.M.; Bandyopadhyay, S.; Taylor, J.; Nirantharakumar, K. Increased Cardiometabolic and Mortality Risk Following Childhood Maltreatment in the United Kingdom. J. Am. Heart Assoc. 2020, 9, e015855. [CrossRef]

21. Higgins, M.W.; Keller, J.B.; Metzner, H.L.; Moore, F.E.; Ostrander, L.D. Studies of Blood Pressure in Tecumseh, Michigan. II. Antecedents in Childhood of High Blood Pressure in Young Adults. Hypertension 1980, 2, 117-123. [CrossRef]

22. Hsu, C.-N.; Tain, Y.-L. Preventing Developmental Origins of Cardiovascular Disease: Hydrogen Sulfide as a Potential Target? Antioxidants 2021, 10, 247. [CrossRef] [PubMed]

23. Thornburg, K.L. The Programming of Cardiovascular Disease. J. Dev. Orig. Health Dis. 2015, 6, 366-376. [CrossRef] [PubMed]

24. Blackmore, H.L.; Ozanne, S.E. Programming of Cardiovascular Disease across the Life-Course. J. Mol. Cell. Cardiol. 2015, 83, 122-130. [CrossRef]

25. Tain, Y.-L.; Hsu, C.-N. Interplay between Oxidative Stress and Nutrient Sensing Signaling in the Developmental Origins of Cardiovascular Disease. Int. J. Mol. Sci. 2017, 18, 841. [CrossRef]

26. Coletti, R.; Almeida-Pereira, G.; Elias, L.L.K.; Antunes-Rodrigues, J. Effects of Hydrogen Sulfide $\left(\mathrm{H}_{2} \mathrm{~S}\right)$ on Water Intake and Vasopressin and Oxytocin Secretion Induced by Fluid Deprivation. Horm. Behav. 2015, 67, 12-20. [CrossRef] [PubMed]

27. Gouin, J.-P.; Carter, C.S.; Pournajafi-Nazarloo, H.; Glaser, R.; Malarkey, W.B.; Loving, T.J.; Stowell, J.; Kiecolt-Glaser, J.K. Marital Behavior, Oxytocin, Vasopressin, and Wound Healing. Psychoneuroendocrinology 2010, 35, 1082-1090. [CrossRef] [PubMed]

28. Olff, M.; Frijling, J.L.; Kubzansky, L.D.; Bradley, B.; Ellenbogen, M.A.; Cardoso, C.; Bartz, J.A.; Yee, J.R.; van Zuiden, M. The Role of Oxytocin in Social Bonding, Stress Regulation and Mental Health: An Update on the Moderating Effects of Context and Interindividual Differences. Psychoneuroendocrinology 2013, 38, 1883-1894. [CrossRef]

29. Polhemus, D.J.; Calvert, J.W.; Butler, J.; Lefer, D.J. The Cardioprotective Actions of Hydrogen Sulfide in Acute Myocardial Infarction and Heart Failure. Scientifica 2014, 2014, 768607. [CrossRef]

30. Szabo, C.; Papapetropoulos, A. International Union of Basic and Clinical Pharmacology. CII: Pharmacological Modulation of $\mathrm{H}_{2} \mathrm{~S}$ Levels: $\mathrm{H}_{2} \mathrm{~S}$ Donors and $\mathrm{H}_{2} \mathrm{~S}$ Biosynthesis Inhibitors. Pharmacol. Rev. 2017, 69, 497-564. [CrossRef]

31. Wang, R. Physiological Implications of Hydrogen Sulfide: A Whiff Exploration That Blossomed. Physiol. Rev. 2012, 92, 791-896. [CrossRef]

32. Merz, T.; Stenzel, T.; Nußbaum, B.; Wepler, M.; Szabo, C.; Wang, R.; Radermacher, P.; McCook, O. Cardiovascular Disease and Resuscitated Septic Shock Lead to the Downregulation of the $\mathrm{H}_{2} \mathrm{~S}$-Producing Enzyme Cystathionine- $\gamma$-Lyase in the Porcine Coronary Artery. Intensive Care Med. Exp. 2017, 5, 17. [CrossRef]

33. Nußbaum, B.L.; McCook, O.; Hartmann, C.; Matallo, J.; Wepler, M.; Antonucci, E.; Kalbitz, M.; Huber-Lang, M.; Georgieff, M.; Calzia, E.; et al. Left Ventricular Function during Porcine-Resuscitated Septic Shock with Pre-Existing Atherosclerosis. Intensive Care Med. Exp. 2016, 4, 14. [CrossRef]

34. Sun, N.-I.; Xi, Y.; Yang, S.; Ma, Z.; Tang, C. Plasma Hydrogen Sulfide and Homocysteine Levels in Hypertensive Patients with Different Blood Pressure Levels and Complications. Zhonghua Xin Xue Guan Bing Za Zhi 2007, 35, 1145-1148.

35. Chen, L.; Ingrid, S.; Ding, Y.; Liu, Y.; Qi, J.; Tang, C.; Du, J. Imbalance of Endogenous Homocysteine and Hydrogen Sulfide Metabolic Pathway in Essential Hypertensive Children. Chin. Med. J. 2007, 120, 389-393. [CrossRef]

36. Wang, P.; Wang, S.C.; Yang, H.; Lv, C.; Jia, S.; Liu, X.; Wang, X.; Meng, D.; Qin, D.; Zhu, H.; et al. Therapeutic Potential of Oxytocin in Atherosclerotic Cardiovascular Disease: Mechanisms and Signaling Pathways. Front. Neurosci. 2019, 13, 454. [CrossRef]

37. Libby, P.; Buring, J.E.; Badimon, L.; Hansson, G.K.; Deanfield, J.; Bittencourt, M.S.; Tokgözŏglu, L.; Lewis, E.F. Atherosclerosis. Nat. Rev. Dis. Primer 2019, 5, 56. [CrossRef] [PubMed]

38. Lo Faro, M.L.; Fox, B.; Whatmore, J.L.; Winyard, P.G.; Whiteman, M. Hydrogen Sulfide and Nitric Oxide Interactions in Inflammation. Nitric Oxide 2014, 41, 38-47. [CrossRef] [PubMed] 
39. Jankowski, M.; Broderick, T.L.; Gutkowska, J. Oxytocin and Cardioprotection in Diabetes and Obesity. BMC Endocr. Disord. 2016, 16, 34. [CrossRef] [PubMed]

40. Całka, J. The Role of Nitric Oxide in the Hypothalamic Control of LHRH and Oxytocin Release, Sexual Behavior and Aging of the LHRH and Oxytocin Neurons. Folia Histochem. Cytobiol. 2006, 44, 3-12.

41. Corrêa, P.B.F.; Pancoto, J.A.T.; de Oliveira-Pelegrin, G.R.; Cárnio, E.C.; Rocha, M.J.A. Participation of INOS-Derived NO in Hypothalamic Activation and Vasopressin Release during Polymicrobial Sepsis. J. Neuroimmunol. 2007, 183, 17-25. [CrossRef] [PubMed]

42. Kadekaro, M.; Summy-Long, J.Y. Centrally Produced Nitric Oxide And The Regulation Of Body Fluid And Blood Pressure Homeostases. Clin. Exp. Pharmacol. Physiol. 2000, 27, 450-459. [CrossRef]

43. Reis, W.L.; Giusti-Paiva, A.; Ventura, R.R.; Margatho, L.O.; Gomes, D.A.; Elias, L.L.K.; Antunes-Rodrigues, J. Central Nitric Oxide Blocks Vasopressin, Oxytocin and Atrial Natriuretic Peptide Release and Antidiuretic and Natriuretic Responses Induced by Central Angiotensin II in Conscious Rats: Central NO Blocks Antidiuresis and Natriuresis. Exp. Physiol. 2007, 92, 903-911. [CrossRef]

44. Coletti, R.; de Lima, J.B.M.; Vechiato, F.M.V.; de Oliveira, F.L.; Debarba, L.K.; Almeida-Pereira, G.; Elias, L.L.K.; AntunesRodrigues, J. Nitric Oxide Acutely Modulates Hypothalamic and Neurohypophyseal Carbon Monoxide and Hydrogen Sulphide Production to Control Vasopressin, Oxytocin and Atrial Natriuretic Peptide Release in Rats. J. Neuroendocrinol. 2019, 31 , e12686. [CrossRef] [PubMed]

45. Ali, I.I.; Al-Salam, S.; Howarth, F.C.; Shmygol, A. Oxytocin Induces Intracellular Ca ${ }^{2+}$ Release in Cardiac Fibroblasts from Neonatal Rats. Cell Calcium 2019, 84, 102099. [CrossRef] [PubMed]

46. Gutkowska, J.; Jankowski, M.; Antunes-Rodrigues, J. The Role of Oxytocin in Cardiovascular Regulation. Braz. J. Med. Biol. Res. 2014, 47, 206-214. [CrossRef]

47. Gutkowska, J.; Jankowski, M.; Lambert, C.; Mukaddam-Daher, S.; Zingg, H.H.; McCann, S.M. Oxytocin Releases Atrial Natriuretic Peptide by Combining with Oxytocin Receptors in the Heart. Proc. Natl. Acad. Sci. USA 1997, 94, 11704-11709. [CrossRef]

48. Krause, S.; Boeck, C.; Gumpp, A.M.; Rottler, E.; Schury, K.; Karabatsiakis, A.; Buchheim, A.; Gündel, H.; Kolassa, I.-T.; Waller, C. Child Maltreatment Is Associated with a Reduction of the Oxytocin Receptor in Peripheral Blood Mononuclear Cells Front. Psychol. 2018, 9, 173. [CrossRef]

49. Jankowski, M.; Hajjar, F.; Kawas, S.A.; Mukaddam-Daher, S.; Hoffman, G.; McCann, S.M.; Gutkowska, J. Rat Heart: A Site of Oxytocin Production and Action. Proc. Natl. Acad. Sci. USA 1998, 95, 14558-14563. [CrossRef]

50. Jankowski, M.; Wang, D.; Hajjar, F.; Mukaddam-Daher, S.; McCann, S.M.; Gutkowska, J. Oxytocin and Its Receptors Are Synthesized in the Rat Vasculature. Proc. Natl. Acad. Sci. USA 2000, 97, 6207-6211. [CrossRef] [PubMed]

51. Szeto, A.; Sun-Suslow, N.; Mendez, A.J.; Hernandez, R.I.; Wagner, K.V.; McCabe, P.M. Regulation of the Macrophage Oxytocin Receptor in Response to Inflammation. Am. J. Physiol.-Endocrinol. Metab. 2017, 312, E183-E189. [CrossRef]

52. Reiss, A.B.; Glass, D.S.; Lam, E.; Glass, A.D.; De Leon, J.; Kasselman, L.J. Oxytocin: Potential to Mitigate Cardiovascular Risk. Peptides 2019, 117, 170089. [CrossRef]

53. Jankowski, M.; Broderick, T.L.; Gutkowska, J. The Role of Oxytocin in Cardiovascular Protection. Front. Psychol. 2020, 11, 2139. [CrossRef]

54. Faghihi, M.; Alizadeh, A.M.; Khori, V.; Latifpour, M.; Khodayari, S. The Role of Nitric Oxide, Reactive Oxygen Species, and Protein Kinase C in Oxytocin-Induced Cardioprotection in Ischemic Rat Heart. Peptides 2012, 37, 314-319. [CrossRef]

55. Gutkowska, J.; Jankowski, M. Oxytocin Revisited: Its Role in Cardiovascular Regulation: Role of OT in Cardiovascular Regulation. J. Neuroendocrinol. 2012, 24, 599-608. [CrossRef] [PubMed]

56. Kajstura, J.; Hosoda, T.; Bearzi, C.; Rota, M.; Maestroni, S.; Urbanek, K.; Leri, A.; Anversa, P. The Human Heart: A Self-Renewing Organ. Clin. Transl. Sci. 2008, 1, 80-86. [CrossRef]

57. Mukaddam-Daher, S.; Yin, Y.-L.; Roy, J.; Gutkowska, J.; Cardinal, R. Negative Inotropic and Chronotropic Effects of Oxytocin. Hypertension 2001, 38, 292-296. [CrossRef]

58. Bernatova, I.; Rigatto, K.V.; Key, M.P.; Morris, M. Stress-Induced Pressor and Corticosterone Responses in Oxytocin-Deficient Mice: Stress Reactivity in Oxytocin-Deficient Mice. Exp. Physiol. 2004, 89, 549-557. [CrossRef]

59. Holst, S.; Uvnäs-Moberg, K.; Petersson, M. Postnatal Oxytocin Treatment and Postnatal Stroking of Rats Reduce Blood Pressure in Adulthood. Auton. Neurosci. 2002, 99, 85-90. [CrossRef]

60. Petersson, M.; Uvnäs-Moberg, K. Postnatal Oxytocin Treatment of Spontaneously Hypertensive Male Rats Decreases Blood Pressure and Body Weight in Adulthood. Neurosci. Lett. 2008, 440, 166-169. [CrossRef] [PubMed]

61. Peters, S.; Slattery, D.A.; Uschold-Schmidt, N.; Reber, S.O.; Neumann, I.D. Dose-Dependent Effects of Chronic Central Infusion of Oxytocin on Anxiety, Oxytocin Receptor Binding and Stress-Related Parameters in Mice. Psychoneuroendocrinology 2014, 42, 225-236. [CrossRef]

62. Wsol, A.; Cudnoch-Jedrzejewska, A.; Szczepanska-Sadowska, E.; Kowalewski, S.; Puchalska, L. Oxytocin in The Cardiovascular Responses to Stress. J. Physiol. Pharmacol. 2008, 59, 123-127.

63. Dobruch, J.; Cudnoch-Jedrzejewska, A.; Szczepanska-Sadowska, E. Enhanced Involvement of Brain Vasopressin V1 Receptors in Cardiovascular Responses to Stress in Rats with Myocardial Infarction: Research Report. Stress 2005, 8, 273-284. [CrossRef] [PubMed] 
64. Fleet, R.; Lespérance, F.; Arsenault, A.; Grégoire, J.; Lavoie, K.; Laurin, C.; Harel, F.; Burelle, D.; Lambert, J.; Beitman, B.; et al. Myocardial Perfusion Study of Panic Attacks in Patients with Coronary Artery Disease. Am. J. Cardiol. 2005, 96, 1064-1068. [CrossRef]

65. Klein, B.Y.; Albers, H.; Anwar, M.; Ludwig, R.J.; Kaidbey, J.H.; Glickstein, S.B.; Welch, M.G. Assessing Cellular Stress and Inflammation in Discrete Oxytocin-Secreting Brain Nuclei in the Neonatal Rat before and after First Colostrum Feeding. J. Vis. Exp. 2018, 141, e58341. [CrossRef]

66. Carter, C.S.; Kenkel, W.M.; MacLean, E.L.; Wilson, S.R.; Perkeybile, A.M.; Yee, J.R.; Ferris, C.F.; Nazarloo, H.P.; Porges, S.W.; Davis, J.M.; et al. Is Oxytocin “Nature's Medicine"? Pharmacol. Rev. 2020, 72, 829-861. [CrossRef] [PubMed]

67. Peleli, M.; Bibli, S.-I.; Li, Z.; Chatzianastasiou, A.; Varela, A.; Katsouda, A.; Zukunft, S.; Bucci, M.; Vellecco, V.; Davos, C.H.; et al. Cardiovascular Phenotype of Mice Lacking 3-Mercaptopyruvate Sulfurtransferase. Biochem. Pharmacol. 2020, 176, 113833. [CrossRef] [PubMed]

68. Donadon, M.F.; Martin-Santos, R.; Osório, F.d.L. The Associations Between Oxytocin and Trauma in Humans: A Systematic Review. Front. Pharmacol. 2018, 9, 154. [CrossRef] [PubMed]

69. Heinrichs, M.; Baumgartner, T.; Kirschbaum, C.; Ehlert, U. Social Support and Oxytocin Interact to Suppress Cortisol and Subjective Responses to Psychosocial Stress. Biol. Psychiatry 2003, 54, 1389-1398. [CrossRef]

70. Juruena, M.F.; Cleare, A.J.; Pariante, C.M. The Hypothalamic Pituitary Adrenal Axis, Glucocorticoid Receptor Function and Relevance to Depression. Rev. Bras. Pisquiatr. 2004, 26, 189-201. [CrossRef]

71. Boyce, W.T.; Ellis, B.J. Biological Sensitivity to Context: I. An Evolutionary-Developmental Theory of the Origins and Functions of Stress Reactivity. Dev. Psychopathol. 2005, 17, 271-301. [CrossRef]

72. Neumann, I.D.; Landgraf, R. Balance of Brain Oxytocin and Vasopressin: Implications for Anxiety, Depression, and Social Behaviors. Trends Neurosci. 2012, 35, 649-659. [CrossRef] [PubMed]

73. Olff, M. Bonding after Trauma: On the Role of Social Support and the Oxytocin System in Traumatic Stress. Eur. J. Psychotraumatol. 2012, 3, 18597. [CrossRef]

74. Kuhlman, K.R.; Vargas, I.; Geiss, E.G.; Lopez-Duran, N.L. Age of Trauma Onset and HPA Axis Dysregulation Among TraumaExposed Youth: Age of First Trauma and HPA Axis Functioning. J. Trauma. Stress 2015, 28, 572-579. [CrossRef] [PubMed]

75. Kundakovic, M.; Champagne, F.A. Early-Life Experience, Epigenetics, and the Developing Brain. Neuropsychopharmacology 2015, 40, 141-153. [CrossRef]

76. Lesse, A.; Rether, K.; Gröger, N.; Braun, K.; Bock, J. Chronic Postnatal Stress Induces Depressive-Like Behavior in Male Mice and Programs Second-Hit Stress-Induced Gene Expression Patterns of OxtR and AvpR1a in Adulthood. Mol. Neurobiol. 2017, 54, 4813-4819. [CrossRef]

77. Ozbay, F.; Fitterling, H.; Charney, D.; Southwick, S. Social Support and Resilience to Stress across the Life Span: A Neurobiologic Framework. Curr. Psychiatry Rep. 2008, 10, 304-310. [CrossRef] [PubMed]

78. Gonzalez, A.; Jenkins, J.M.; Steiner, M.; Fleming, A.S. The Relation between Early Life Adversity, Cortisol Awakening Response and Diurnal Salivary Cortisol Levels in Postpartum Women. Psychoneuroendocrinology 2009, 34, 76-86. [CrossRef]

79. Nicolson, N.A.; Davis, M.C.; Kruszewski, D.; Zautra, A.J. Childhood Maltreatment and Diurnal Cortisol Patterns in Women with Chronic Pain. Psychosom. Med. 2010, 72, 471-480. [CrossRef]

80. Kirsch, P. Oxytocin Modulates Neural Circuitry for Social Cognition and Fear in Humans. J. Neurosci. 2005, 25, 11489-11493. [CrossRef]

81. Laviola, G.; Busdraghi, L.M.; Meschino, N.; Petrella, C.; Fiore, M. Aberrant Early in Life Stimulation of the Stress-Response System Affects Emotional Contagion and Oxytocin Regulation in Adult Male Mice. Int. J. Mol. Sci. 2021, 22, 5039. [CrossRef] [PubMed]

82. Yehuda, R.; Bierer, L.M.; Schmeidler, J.; Aferiat, D.H.; Breslau, I.; Dolan, S. Low Cortisol and Risk for PTSD in Adult Offspring of Holocaust Survivors. Am. J. Psychiatry 2000, 157, 1252-1259. [CrossRef]

83. Brown, C.A.; Cardoso, C.; Ellenbogen, M.A. A Meta-Analytic Review of the Correlation between Peripheral Oxytocin and Cortisol Concentrations. Front. Neuroendocrinol. 2016, 43, 19-27. [CrossRef] [PubMed]

84. Tan, H.; Zou, W.; Jiang, J.; Tian, Y.; Xiao, Z.; Bi, L.; Zeng, H.; Tang, X. Disturbance of Hippocampal $\mathrm{H}_{2} \mathrm{~S}$ Generation Contributes to CUMS-Induced Depression-like Behavior: Involvement in Endoplasmic Reticulum Stress of Hippocampus. Acta Biochim. Biophys. Sin. 2015, 47, 285-291. [CrossRef]

85. Liu, S.-Y.; Li, D.; Zeng, H.-Y.; Kan, L.-Y.; Zou, W.; Zhang, P.; Gu, H.-F.; Tang, X.-Q. Hydrogen Sulfide Inhibits Chronic Unpredictable Mild Stress-Induced Depressive-Like Behavior by Upregulation of Sirt-1: Involvement in Suppression of Hippocampal Endoplasmic Reticulum Stress. Int. J. Neuropsychopharmacol. 2017, 20, 867-876. [CrossRef]

86. Brenner, L.A. Neuropsychological and Neuroimaging Findings in Traumatic Brain Injury and Post-Traumatic Stress Disorder. Dialogues Clin. Neurosci. 2011, 13, 311-323. [CrossRef] [PubMed]

87. Mauri, M.C.; Paletta, S.; Di Pace, C.; Reggiori, A.; Cirnigliaro, G.; Miserocchi, G. Depression and Post-Traumatic Brain Injury: Clinical and Neuropsychological Characteristics. Dual Diagn. Open Access 2017, 2, 29. [CrossRef]

88. Howland, R.H. Vagus Nerve Stimulation. Curr. Behav. Neurosci. Rep. 2014, 1, 64-73. [CrossRef] [PubMed]

89. Tracey, K.J. Physiology and Immunology of the Cholinergic Antiinflammatory Pathway. J. Clin. Investig. 2007, 117, 289-296. [CrossRef]

90. Lozić, M.; Greenwood, M.; Šarenac, O.; Martin, A.; Hindmarch, C.; Tasić, T.; Paton, J.; Murphy, D.; Japundžić-Žigon, N. Overexpression of Oxytocin Receptors in the Hypothalamic PVN Increases Baroreceptor Reflex Sensitivity and Buffers BP Variability in Conscious Rats: Oxytocin Receptors in Autonomic Circulatory Control. Br. J. Pharmacol. 2014, 171, 4385-4398. [CrossRef] [PubMed] 
91. Garrott, K.; Dyavanapalli, J.; Cauley, E.; Dwyer, M.K.; Kuzmiak-Glancy, S.; Wang, X.; Mendelowitz, D.; Kay, M.W. Chronic Activation of Hypothalamic Oxytocin Neurons Improves Cardiac Function during Left Ventricular Hypertrophy-Induced Heart Failure. Cardiovasc. Res. 2017, 113, 1318-1328. [CrossRef]

92. Mioni, C.; Bazzani, C.; Giuliani, D.; Altavilla, D.; Leone, S.; Ferrari, A.; Minutoli, L.; Bitto, A.; Marini, H.; Zaffe, D.; et al. Activation of an Efferent Cholinergic Pathway Produces Strong Protection against Myocardial Ischemia/Reperfusion Injury in Rats. Crit. Care Med. 2005, 33, 2621-2628. [CrossRef]

93. Zhang, X.-Y. Effects of Nuclei Ambiguus and Dorsal Motor Nuclei of Vagus on Gastric $\mathrm{H}^{+}$and $\mathrm{HCO}_{3}{ }^{-}$Secretion in Rats. World J. Gastroenterol. 2006, 12, 3271. [CrossRef] [PubMed]

94. Elorza-Ávila, A.R.; Reyes-Lagos, J.J.; Hadamitzky, M.; Peña-Castillo, M.Á.; Echeverría, J.C.; Ortiz-Pedroza, M.d.R.; Lückemann, L.; Schedlowski, M.; Pacheco-López, G. Oxytocin's Role on the Cardiorespiratory Activity of Endotoxemic Rats. Respir. Physiol. Neurobiol. 2017, 236, 19-22. [CrossRef] [PubMed]

95. Sun, H.-Z.; Yu, K.-H.; Ai, H.-B. Role of Hydrogen Sulfide within the Dorsal Motor Nucleus of the Vagus in the Control of Gastric Function in Rats. Neurogastroenterol. Motil. 2015, 27, 618-626. [CrossRef] [PubMed]

96. Gan, X.-B.; Liu, T.-Y.; Xiong, X.-Q.; Chen, W.-W.; Zhou, Y.-B.; Zhu, G.-Q. Hydrogen Sulfide in Paraventricular Nucleus Enhances Sympathetic Activity and Cardiac Sympathetic Afferent Reflex in Chronic Heart Failure Rats. PLoS ONE 2012, 7, e50102. [CrossRef]

97. Austgen, J.R.; Hermann, G.E.; Dantzler, H.A.; Rogers, R.C.; Kline, D.D. Hydrogen Sulfide Augments Synaptic Neurotransmission in the Nucleus of the Solitary Tract. J. Neurophysiol. 2011, 106, 1822-1832. [CrossRef] [PubMed]

98. Okazaki, M.; Uozu, S.; Sato, Y.; Matsumoto, M.; Koganezawa, T. Endogenous Hydrogen Sulfide Maintains Eupnea in an in Situ Arterially Perfused Preparation of Rats. Commun. Biol. 2020, 3, 583. [CrossRef]

99. Makarenko, V.V.; Nanduri, J.; Raghuraman, G.; Fox, A.P.; Gadalla, M.M.; Kumar, G.K.; Snyder, S.H.; Prabhakar, N.R. Endogenous $\mathrm{H}_{2} \mathrm{~S}$ Is Required for Hypoxic Sensing by Carotid Body Glomus Cells. Am. J. Physiol. Cell Physiol. 2012, 303, C916-C923. [CrossRef]

100. Xiao, L.; Wu, Y.; Wang, R.; Liu, Y.; Wang, F.; He, R. Hydrogen Sulfide Facilitates Carotid Sinus Baroreceptor Activity in Anesthetized Male Rats. Chin. Med. J. 2007, 120, 1343-1347. [CrossRef]

101. Gerritsen, R.J.S.; Band, G.P.H. Breath of Life: The Respiratory Vagal Stimulation Model of Contemplative Activity. Front. Hum. Neurosci. 2018, 12, 397. [CrossRef]

102. Dudeja, J.P. Scientific Analysis of Mantra-Based Meditation and Its Beneficial Effects: An Overview. Int. J. Adv. Sci. Technol. Eng. Manag. Sci. 2017, 3, 21-26. [CrossRef]

103. Dusek, J.A.; Chang, B.H.; Zaki, J.; Lazar, S.; Deykin, A.; Stefano, G.B.; Wohlhueter, A.L.; Hibberd, P.L.; Benson, H. Association between oxygen consumption and nitric oxide production during the relaxation response. Med. Sci. Monit. 2005, 12, CR1-CR10. [PubMed]

104. Kaliman, P.; Álvarez-López, M.J.; Cosín-Tomás, M.; Rosenkranz, M.A.; Lutz, A.; Davidson, R.J. Rapid Changes in Histone Deacetylases and Inflammatory Gene Expression in Expert Meditators. Psychoneuroendocrinology 2014, 40, 96-107. [CrossRef]

105. Kabat-Zinn, J. Mindfulness-based stress reduction (MBSR). Constr. HumSci. 2003, 8, 73.

106. Amarasekera, A.T.; Chang, D. Buddhist meditation for vascular function: A narrative review. Integr. Med. Res. 2019, 8, 252-256. [CrossRef] [PubMed]

107. Van Cappellen, P.; Way, B.M.; Isgett, S.F.; Fredrickson, B.L. Effects of Oxytocin Administration on Spirituality and Emotional Responses to Meditation. Soc. Cogn. Affect. Neurosci. 2016, 11, 1579-1587. [CrossRef]

108. Machida, S.; Sunagawa, M.; Takahashi, T. Oxytocin Release during the Meditation of Altruism and Appreciation (Arigato-Zen). Int. J. Neurol. Res. 2018, 4, 364-370. [CrossRef]

109. Ito, E.; Shima, R.; Yoshioka, T. A Novel Role of Oxytocin: Oxytocin-Induced Well-Being in Humans. Biophys. Physicobiol. 2019, 16, 132-139. [CrossRef]

110. Kim, D.H.; Moon, Y.S.; Kim, H.S.; Jung, J.S.; Park, H.M.; Suh, H.W.; Kim, Y.H.; Song, D.K. Effect of Zen Meditation on serum nitric oxide activity and lipid peroxidation. Prog. Neuropsychopharmacol. Biol. Psychiatry 2005, 29, 327-331. [CrossRef] [PubMed]

111. Bellosta-Batalla, M.; Blanco-Gandía, M.; Rodríguez-Arias, M.; Cebolla, A.; Pérez-Blasco, J.; Moya-Albiol, L. Brief Mindfulness Session Improves Mood and Increases Salivary Oxytocin in Psychology Students. Stress Health 2020, 36, 469-477. [CrossRef] [PubMed]

112. Mayer, S. Studien zur Physiologie des Herzens und der Blutgefaesse 6.Abhandlung: Ueber spontane Blutdruckschwenkungen. [Studies on the physiology of the heart and the blood vessels 6. Discourse on fluctuations in blood pressure]. Sitz Ber Akad Wiss Wien Mathe Naturwiss Kl Anat 1876, 74, 281-307.

113. Bernardi, L.; Sleight, P.; Bandinelli, G.; Cencetti, S.; Fattorini, L.; Wdowczyc-Szulc, J.; Lagi, A. Effect of Rosary Prayer and Yoga Mantras on Autonomic Cardiovascular Rhythms: Comparative Study. BMJ 2001, 323, 1446-1449. [CrossRef] [PubMed]

114. Peressutti, C.; Martín-González, J.M.; García-Manso, J.M. Does Mindfulness Meditation Shift the Cardiac Autonomic Nervous System to a Highly Orderly Operational State? Int. J. Cardiol. 2012, 154, 210-212. [CrossRef]

115. Fox, K.C.R.; Nijeboer, S.; Dixon, M.L.; Floman, J.L.; Ellamil, M.; Rumak, S.P.; Sedlmeier, P.; Christoff, K. Is Meditation Associated with Altered Brain Structure? A Systematic Review and Meta-Analysis of Morphometric Neuroimaging in Meditation Practitioners. Neurosci. Biobehav. Rev. 2014, 43, 48-73. [CrossRef] [PubMed]

116. Erdman, S.E. Microbial Muses: Threads of Our Inner Wisdom. Challenges 2021, 12, 10. [CrossRef] 